This is the accepted manuscript of the article, which has been published in JCMS: Journal of Common Market Studies. 2019, 57(S1), 62-76. https://doi.org/10.1111/jcms.12949

Emanuela Lombardo and Johanna Kantola

\title{
European integration and disintegration: Feminist perspectives on inequalities and social justice
}

The year 2018 marked the tenth anniversary of unprecedented challenges to the European integration processes. Beginning in 2008 the global financial crisis, which later turned into a Eurocrisis, started a chain of events that shook the process of European integration. From Brexit to the rise of European populist parties, and attacks to democracy in member states such as Hungary and Poland, each ensuing development suggests a move towards European disintegration. At the same time, the EU sought to reply to these challenges by strengthening integration is some areas. The EU established new mechanisms of economic governance, moving decision-making power away from member states and the European Parliament, to new undemocratic actors. A stronger social dimension was debated too as evidenced by the European Pillar of Social Rights (EPSR). In many ways, 2018 is the year when the European disintegration as a process enters mainstream discourse and thinking. The juxtaposition of deeper integration in some areas, coupled with less democratic forms of governance, can be understood also as part of this balancing between integration and disintegration that is at the very core of the year under examination here.

Scholarly debates about the European crisis are marked by contestation about whether we can speak of disintegration, and how to identify the phenomenon (see Rittberger and Blauberger, 2018). In this article, we ask what insights feminist political analysis can bring to these contradictory processes of integration and disintegration and how we theorise these competing processes. We argue that feminist political analysis shows that mainstreaming gender as a core analytical category of European integration theory becomes a litmus test for the whole integration process. It is an indicator of the democratic health of the Union. Scrutinizing real-world challenges to European integration from an intersectional gender perspective reveals that when gender equality is dismantled, attacked or marginalised in the EU, it is not just one tiny slice of social and political reality that is affected, but the democratic character of whole integration process is at stake.

We apply a five-fold analytical framework of gender (Kantola and Lombardo, 2017a; 2017b) to selected key challenges to European integration to illuminate these questions and the significance of different gender perspectives for understanding European integration (EI). We suggest that of our five feminist approaches, which we have termed (i) women, (ii) gender, (iii) deconstruction, (iv) 
intersectionality and (v) postdeconstruction, the first two - women and gender - have been most extensively applied in gender and politics research. In this article, we highlight the importance of the last three. Our key argument is that European integration (EI) theory can improve its analytical capacity vis-à-vis current disintegration challenges in theory and real world by including analytical and methodological insights from feminist deconstruction, intersectional and postdeconstruction approaches. These are particularly apt to link theory and praxis, to address power dynamics between different embodied people, and to identify discursive and intersectional oppositions and counterforces, as well as affective contexts in which current processes of disintegration and integration develop.

\section{Theorizing European disintegration}

Our argument draws upon two sets of recent scholarly debates: first, EU literature on European disintegration, and, second, the gender and EU literature on European integration. From the former, we adopt the idea that in contrast to much of the current literature, it is imperative to focus on realworld challenges to integration and its discursive and affective framings. From the latter, we discern the centrality of gendered power relations to analysing both integration and disintegration.

European integration theory faces a number of challenges to make sense of the new political context of potential disintegration. Classic definitions of European integration (EI) conceive it as a process in which political actors give rise to a 'new political community' because they 'are persuaded to shift their loyalties, expectations and political activities towards a new centre, whose institutions possess or demand jurisdiction over pre-existing national states' (Haas, 1958, p. 16). More recently, Webber (2017, p. 336) identified three dimensions of political (dis)integration, a horizontal dimension, that concerns the increase or reduction in the number of countries that join the EU, a vertical dimension, that includes the increase or reduction of competence and power of EU supranational institutions such as the European Commission, Parliament and Court of Justice, and a sectoral dimension that implies a growth or decrease in the number of issue areas in which the EU adopts common policies in the member states.

'Differentiated integration', in turn, is the process in which member states are going towards a similar goal of involvement in the Union but at different speeds. Yet, in the face of member states' increasing differentiation in the post-crisis context, scholars now treat differentiated integration as a "normal' feature of regional integration' (Leruth and Lord, 2015, p. 760). Furthermore, the profound transformations of the EU political context exemplified in Brexit, populist and Eurosceptic parties, 
have recently moved researchers to argue that understanding processes of integration requires studying not only differentiated integration but also differentiated 'disintegration' (Rittberger and Blauberger, 2018; Leruth and Lord, 2015).

Disintegration had been notably absent from European integration theories until recently. However, to respond to the EU crisis political setting, concepts and theories are being refined in order to improve our understanding not only of why and how states integrate but also why and how they disintegrate (Rittberger and Blauberger, 2018). Drawing on these debates, while the existence of disintegration is contested, some procedural elements allow us to define the phenomenon. These include: the exit of states (Brexit) (Schimmelfenning, 2017; Rosamond, 2016), or horizontal dimension of disintegration (Webber, 2017); the reduction of competence of EU supranational institutions, or vertical disintegration (Webber, 2017); a decrease in the issue areas in which the EU adopts common policies, or sectoral disintegration (Webber, 2017); and democratic decline in countries such as Hungary and Poland and in some of the political responses to the economic crisis (Kreuder-Sonnen, 2018).

We also take from the discussion the message that it is important to address both integration and disintegration as part of the same process (Rosamond, 2016). European integration is not a linear process. By looking at integration and disintegration as part of the same process ensures a greater analytical balance, thus enabling a more comprehensive and sophisticated understanding of this complex political process. Addressing disintegration and integration together in the political phenomena that characterised EU politics in 2018 will reveal the contradictory picture of the Union's socio-political reality and the dynamics of enabling and repressive power that are at work.

Tanja Börzel (2018, p. 480) puts is clearly: 'If we do not find compelling evidence for disintegration, maybe our search has been tainted by theories that have missed out on important dimensions' of analysis ‘beyond economic transactions, regional institution-building, and European identity’ and comprehensive analyses that account for 'variation across time and, possibly, issues. If discourses become more nationalist and practices more non-compliant, we need theories that tell us how and when these tendencies of disintegration will undermine economic transactions, regional institutionbuilding, and the dependable expectations of peaceful change among Europeans.' She therefore recommends European integration scholars that 'Rather than interdependence, institutions and identities, they should be concerned about discursive and behavioural practices that could turn into disintegration.’ (Börzel, 2018, p. 480, emphasis ours). 
While EI theory has clearly identified the problems the EU is currently facing and advanced in their conceptualization, it has not addressed such problems in depth, and it is missing out important analytical and methodological dimensions. In other words, to grasp disintegration, we need to give more relevance to the study of nationalist exclusionary discourses and practices, as well as dynamics of gender and other inequalities that have intensified in the context of the EU economic crisis and Brexit. Understanding EU disintegration requires new lenses that can be offered by less hegemonic approaches in the EI discipline. This is why we argue that gendering EI through feminist approaches is especially apt to analytically face current EU (dis)integration challenges that have come to define EU politics in 2018.

\section{Gendering European integration theories}

Gender scholars who have explicitly engaged with European integration theories denounce the theories' gender blindness and masculine bias (Hoskyns, 2004; 1996; Kronsell, 2012; 2016; Abels and MacRae, 2016). The European integration theories, which seek to explain why and how integration occurs, are based on depictions of abstracted processes, structures and actors, where their gendered underpinnings are not of interest. Mainstream scholarship has paid little attention to the fact that most key actors are men (as heads of states, commissioners, bankers, or top civil servants) or masculine (such as states, EU institutions); the structures of economic and political integration may signify different things to women, men, minorities living in the EU or working within its institutions (e.g. feminine characteristics and life situations may be devalued as opposed to masculine ones); and integration processes themselves may be gendered, prioritise masculine structures and fail to advance gender equality and diversity (Haastrup and Kenny, 2016). The same lack of understanding of the way gender shapes the world is evident in the concepts and methods used to study European integration (Kronsell, 2012). The omission of gender analyses in dominant European integration approaches reduces scholars' analytical potential for understanding the EU since it 'produce[s] ignorance of the asymmetrical impact of critical junctures (e.g., Brexit) and governance structures (e.g., negotiations) on different socioeconomic groups’' (Guerrina et al, 2018, p. 254).

At the same time - and perhaps as a result of it - gender and EU studies have not made sustained efforts to theorize 'integration as such' (Abels and MacRae, 2016, p. 22), with a couple of notable exceptions (Abels and MacRae, 2016; Kronsell, 2005, 2012, 2016. According to Abels and MacRae (2016) a gender approach to integration theory boils down to three issues. First, a 'new epistemology and ontological approach' and 'power relations, agency, and dynamics of formal and informal 
institutional interactions' (2016, p. 27). Second, the fact that there is not one feminist approach but rather many. Third, 'as integration scholarship has generally reached the end of the grand debates and there has been a blurring of formerly strict boundaries, the opportunity opens up for an increased gendered theorizing' (Abels \& MacRae, 2016, p. 22).

We make two observations and wish to make two contributions to these debates. The first is that despite the sensitivity to different perspectives, Abels and MacRae (2016) deal only with two gender approaches to political analysis: namely, what we would term "women”, and "gender" approaches (Kantola and Lombardo, 2017a; 2017b). Our assessment of 2018 is a call for the need to draw on three other feminist approaches to political analysis: deconstruction, intersectionality and postdeconstruction.

We have discussed the framework of the five approaches at length elsewhere (Kantola and Lombardo, 2017a; 2017b) but we here link them to integration theory in a novel way. To analyse European integration through the perspective of women and integration signifies asking where women are in European integration processes and theory and adding women to existing EI theories. Hence women and integration would illustrate the marginal position of women and the dominant position of men in key places, processes and institutions of European integration. Gender is reduced to women, which in turn is seen as a unified and stable category with common interests (Haastrup and Kenny, 2016, p. 204).

In the gender and integration approach gender is an analytical category. This shifts scholarly attention to gendered structures of European integration: how gender, gender power and different values attached to masculinities and femininities underpin the very processes and structures. Haastrup and Kenny explain how historic exclusion of women from these political institutions has meant that sets of masculine practices have become dominant norms and logics of the institutions (2016, p. 202). This more expansive notion of gender requires, as Hoskyns suggests (2004, p. 33), a rethink of the very concepts of European integration. One example is the notion of power, which is narrowly defined in mainstream integration theory (Bieling and Diez 2016, p. 282). This omits the broader notions of power according to feminist theory as a relation between diverse embodied people rather than just between institutions or polities (Kronsell, 2012), that not only constrains women's opportunities through domination but also empowers gendered subjects through resistance to domination. 
We discern three additional feminist approaches to integration theory and argue that "crisis” makes them particularly pertinent. Deconstruction and integration exposes dominant gendered discourses and norms which underpin ideas about integration, having powerful effects on people. Three issues become central to gender in relation to social constructionism and EI theory: European integration as a social construction; the ways in which structures and agency are mutually constituted; and the role of norms and discourses (Lombardo, 2016, p. 124). Feminist analyses of EU gender policy have been inspired by this deconstructionist approach and have illustrated how the problem of gender inequality in the EU and its solutions can be represented in different ways, and that a particular problem conceptualization or solution to the problem that is fixed for some time is at the same time silencing other representations of the problem and solutions, with gender and intersectional effects on the people (e.g. Kantola and Lombardo, 2017b; Cavaghan, 2017; Rolandsen Agustín, 2013; Verloo, 2007). A more Foucauldian governmentality approach to integration addresses 'how gendered norms and rationalities of government are discursively constructed through policies and politics and how these in turn are influenced by mostly essentialist gender norms and assumptions’ (Wöhl, 2016, p. 239). Governmentality approaches stress the ambivalent effects of EU's political and economic power, which can be both repressive and enabling/empowering (Wöhl, 2016, p. 239; Eräranta and Kantola, 2016).

Intersectionality and integration approach analyses how gender intersects with other inequality categories such as race, ethnicity, class, disability, or sexuality, and the power hierarchies, privileges, and exclusions that are produced between embodied people. Power in this approach is related to interacting dynamics of sexism-racism-homophobia-classism and other privileging/marginalizing inequalities that people experience, and politics produces. Inequality structures shape lives of different women and men in the EU and beyond (structural intersectionality) and inform the policies put forward by the Union (political intersectionality) (cf. Crenshaw, 1991; Rolandsen Agustín, 2013). EI theory most often fails to account for these acute inequalities and power imbalances at the heart of the EU (Lombardo, 2016, p. 131). This is all the more shocking considering the colonial history of the EU, the way this past lives on in the postcolonial presence, and the institutionalised racism and inequalities that underpin its processes and policies (Bassel and Emejulu, 2017).

Post-deconstruction and integration is a novel approach which is widely debated in feminist theory and cultural studies but still not employed in gender and EU studies or political analysis. Postdeconstruction 'approaches are interested in understanding what affects, emotions and bodily material do in gender and politics' (Kantola and Lombardo, 2017, p. 43). According to these 
perspectives, significant social change cannot be achieved solely by deconstructing discourses but rather need to understand and alter the material conditions, affects, and the interests that these serve (Coole and Frost, 2010, p. 25). Affects and emotions are perceived as shaping individual and collective bodies, cementing sexed and raced relations of domination, and being collectively organised around particular figures, (e.g. the 'asylum seeker'), by for instance attaching emotions of 'disgust' or 'empathy' towards people who are constructed as 'the other' (Pedwell, 2014; Ahmed, 2004). Post-deconstruction approaches have been marginal in both European integration and gender and politics research. However, these approaches are relevant for understanding how emotions and affects currently challenge European integration. Populism is a good example of the need to employ post-deconstruction perspective to understand how gendered and raced emotions are mobilised in a Union in which prime ministers attack academic institutions and gender studies (e.g. Orban's Hungarian government) and scientific data (e.g. Salvini’s Italian government attacks data on the role of migrant women and men in the pension system).

\section{Applying feminist approaches to European disintegration: The cases of economic crisis, populism and Brexit in 2018.}

In this section, we analyse three key challenges to European integration that became manifest in 2018 through the three feminist approaches discussed above. Our cases are illustrative and our key aim is to make visible what feminist approaches can add to our understanding of integration and disintegration in the current European politics. To do this we discuss, first, the economic crisis though intersectionality; second, populism through deconstruction; and third, Brexit through postdeconstruction.

\section{Economic crisis and intersectionality}

The economic crisis has challenged European integration by revitalising longstanding tensions such as the uneasy relationship between economic productivity and the EU social model, inequalities between member states or the democratic deficit (Kantola and Lombardo, 2017; Walby, 2015). Analyses of the economic crisis from intersectional lenses reveal dimensions of disintegration such as the marginalisation of minoritized women and men in the integration project, sectoral disintegration in different policy fields, and of de-democratization. At the same time, they also show pressures towards further integration that the crisis has triggered, which reveal that processes of inclusion, gender equality policy advance and re-democratization are in course. 
EU austerity politics has created socio-economic and other inequalities between European citizens (for example by impoverishing Greek citizens), and exclusion/marginalization of third country nationals. Intersectionality moves us to ask the question of 'integration/disintegration for whom?'. The exclusion and marginalization of EU women citizens produced by the crisis could be taken as an indicator of the declining capacity of EU to include them, through targeted policies, and thus be interpreted as a sign of sectorial disintegration. Gender analyses show that austerity cuts to the public sector services, benefits and jobs, unemployment, and poverty have increased in the EU, especially for racialised minority women (Karamessini, 2014).

Above all, when intersectional lenses are adopted, integration failures, so prevalent in the analysis of 2018, appear as longstanding issues rather than exceptional problems brought about by the crisis. While prevailing narratives of the crisis picture the negative effects of austerity politics on women in EU member states in terms of their increasing inequality and precarity in the labour market, this representation, argue Bassel and Emejulu (2017), reflects the experience of majority women who enjoyed more economically privileged situations before the crisis. Minority women, in contrast, have to face 'routinised crises' in their everyday work and life, due to economic and social inequalities based on their race, ethnicity, class, sexuality, legal status, or religion. Work precarity, everyday inequalities, and lack of full integration in the EU political community predated the 2008 crisis for minority women. The decline in sectoral integration as a result of the economic crisis, exists only when seen from the perspective of some, not all women, since demands of minority women are still unanswered by the EU (Bassel and Emejulu, 2017).

As the EU economic governance in times of crisis has promoted gendered and racialized hierarchies (Klatzer and Schlager, 2014), similarly, the EU official narrative of a positive economic recovery in 2017 is problematized by Cavaghan and O’Dwyer (2018) who ask: ‘A Recovery for Whom?’. Whose interests are considered when EU institutions claim we have recovered normality in a 'post-crisis' context in which women's unpaid reproductive work has increased as a consequence of austerity politics and backsliding EU gender equality policies? Whose demands are included when ethnic minority women are still unequally treated in the EU labour market and society? When intersectional lenses are applied to the analysis of the economic crisis, the European integration process presents new and old disintegrative dynamics.

At the same time, intersectional approaches allow researchers to identify integrative processes that the economic crisis had triggered. Anti-austerity feminist struggles that civil society enacted as a 
response to the economic crisis have contributed to promoting a project of European integration based on equality, solidarity, inclusion and democracy. Feminist activists in Spain weaved intersecting alliances with Indignados social movements struggling for real democracy and defending public health, housing, and education policies from neoliberal attacks that intensified during the economic crisis, at the same time that they advanced the feminist project of gender equality (Lombardo, 2017). Ethnic minority women in UK and France made intersecting alliances to promote social justice and counteract the invisibilization of their longstanding demands when the privileged white middle classes now face the precarious economic and societal conditions that constitute the normality for minority women (Bassel and Emejulu, 2017). New autonomous feminist movements and trade unions in Finland joined in struggles against the neoliberalism, racism and conservatism of right-wing government's austerity politics (Elomäki and Kantola, 2017; 2018). Such feminist struggles, often intersecting alliances with other social movements, promote a project of European integration based on equality and social inclusion. Moreover, they have promoted dynamics of re-democratization of the European public sphere in response to austerity politics (Verloo and Paternotte, 2018; Roggeband and Krizsán, 2018), that we consider a key element of European integration.

To account for such integrative dynamics, EI theory needs to include the study of intersectional empowering coalitions of equality projects. Analysis of EU policymaking from intersectional perspectives also contributes to EI theory by showing the extent to which EU policies are inclusive of different people and therefore capable of promoting further integration among the people of Europe’s increasingly diverse societies (Lombardo and Rolandsen Agustín, 2016).

\section{Populism and deconstruction}

For decades the EU has been used strategically and discursively by national actors for a variety of purposes. It has become an easy target for populist politicians to blame for a multiplicity of national, European and global problems. Populist right parties challenge the EU's legitimacy to represent the people and reject European integration, presenting themselves as the 'only defenders of national sovereignty and culture', both threatened by the process of European integration and globalization (Gómez-Reino, 2018, p. 63). EU’s bureaucracy is represented as excessive, its legislation and laws as irrelevant or harmful to national interests, and the EU is argued to lack democratic legitimacy (Pirro and van Kessel, 2017, p. 407). While increasing questioning by populist Eurosceptic parties of EU supranational competence has not led to actual renationalization of EU policies, it is a sign of a shift towards 'vertical' disintegration or the decreasing of the power of supranational institutions, at least in the discourse (Webber, 2017, p. 336). 
Anti-gender discourses are an important part of populist anti-EU integration rhetoric because the EU tends to be associated with gender equality. Deconstruction approaches show that, if gender equality was marginalised in the narrative of the economic crisis, populist discourses manifest direct opposition against gender equality. Mieke Verloo (2018, p. 6) defines such opposition as

'any activity in which a perspective opposing feminist politics and gender+ equality policy is articulated in a way that can be expected to influence or is actually influencing politics or policymaking at any stage.’

This opposition goes against EU Treaty articles on equality and antidiscrimination and has detrimental effects on democracy. Deconstructionist perspectives show how the discourse of radical right populist groups in Europe is anti-feminist, anti-LGBTI, conservative, nationalist, racist, xenophobic, and Islamophobic (Köttig, Bitzan and Petö, 2017; Spierings and Zaslove, 2015; Norocel, 2013) and expose the ways in which gender equality discourse is used against migrant people (Keskinen, Norocel \& Jørgensen, 2016; Siim et al., 2016; Meret, 2015). Discourses against 'gender ideology', which misrepresent gender equality policies and gender studies, presenting them as dangerous, reveal that gender is a scapegoat for right populists both at national level (Kuhar and Paternotte, 2017) and in MEPs’ misogynist speeches (Kantola and Rolandsen Agustín, 2016; 2019). Anti-gender discourses foster disintegration because, as Kuhar and Paternotte (2017) explain, they construct the EU as the elites' gender equality project as opposed to the social class and the people, thus delegitimizing the EU and fuelling more Euroscepticism. For radical right groups in the EP, the EU should not intervene in gender equality, emphasising subsidiarity and treating this as a national issue.

Sectoral disintegration through backsliding and dismantling of gender equality policies has occurred in member states such as Poland and Hungary in the last ten years (Roggeband and Krizsán, 2018). This has gone together with the discursive delegitimation of gender equality policies in 'morality' areas, such as abortion, sexual and reproductive rights, sexual education, family policies, and violence against women. If gender were taken more seriously in EI theory, the analysis of discursive attacks to gender equality and backsliding in gender policies in some member states could anticipate Eurosceptic trends. This is because gender equality is perceived as an EU value that the EU is supporting. Interestingly, in Central European Countries 'Anti-discrimination policies, economic issues such as women in the labour market or in leadership, equal pay, and sexual harassment, which 
are all mainly regulated in alignment with EU norms, have been left remarkably untouched by the wave of policy dismantling.” (Roggeband and Kriszán, 2018, p. 379). This is a profound finding, which could show that European integration still holds, because discursive attacks and policy backsliding have affected only those areas which the EU does not regulate. Once again, feminist political analysis can provide EI theory with insights to better understand current (dis)integration processes.

Gender research also connects opposition to gender equality - expressed by populist parties and other forces - with de-democratization (Verloo, 2018; Verloo and Paternotte, 2018). Discursive attacks to gender equality are considered in gender research as attacks to democracy because gender equality is not just one slice, but it is an integral part of democracy. As a result, when gender equality is attacked, democracy is attacked, and vice-versa. Feminist scholarship brings empirical evidence about the 'clear democratic decline in Europe’ and its detrimental effects on equality and inclusion (Verloo, 2018, p. 238) and suggests the need to include in EI studies theories about opposition and dedemocratization and their interaction. The curtailing of space for civil society's expression and free speech in Europe has detrimental effects on feminist movements' struggles, which in turn has further de-democratization consequences considering the contribution of feminist struggles to the democratization of the political space through their challenge to processes of domination and exclusion (Verloo, 2016; Verloo and Paternotte, 2018). If EI theory does not address opposition to gender equality and LGBT rights it will miss out important indicators of disintegration and dedemocratization that have become highly salient in 2018.

Feminist approaches point at a variety of integrationist dynamics and helpful insights for EI. The role of civil society, in particular feminist movements' discursive and material struggles in reaction to right populism, is an important issue that gender approaches bring to light and which should be included in EI analyses, since it indicates empowering dynamics towards democratization which are interesting for integration. In Finland, for example, right-wing populism has activated women into politics through a new feminist movement that is much more mobilized and articulates discourses that contrast the radical right agenda of The Finns Party’s populist party (Elomäki and Kantola, 2018).

Deconstruction approaches provide elements to capture the genderedness of contexts that counteract disintegration practices and mobilise people towards European integration grounded on solidarity and human rights. One example is the intersectional activism and solidarity movements that European citizens have formed to counteract right populism and neo-nationalism's exclusionary processes, and 
support equality and inclusive human rights in Europe (Siim, Krasteva and Saarinen, 2018). To grasp integrative dynamics, EI theory needs to include the study of citizens' solidarity movements (e.g. with migrants, refugees and asylum-seekers). Another example of integrative practices is offered by politicians who speak in a different, more reconciling and Eurofriendly language than the oppositional tones of right populist leaders (e.g see Macron and Sánchez as compared to Orban and Salvini) or that have revitalised practices of dialogue with European citizens about the future of the Union (e.g. Macron, Timmermans).

Deconstructionist approaches help to understand why right populists oppose to gender in their discourses, how gender is used in populist discourses to attack the democracy of the European polity; and how gender is central in integrative dynamics when people react against the racism, sexism, xenophobia and homophobia of right populist parties to defend equality, inclusion and democracy. While right populism is explicitly opposing gender equality (and expressing Eurosceptic positions), gender analyses of European left populism show that at a discursive level left-wing populist parties such as Podemos in Spain are still better allies to feminist politics than right-wing populists (Kantola and Lombardo, 2019).

In conclusion, deconstructionist approaches contribute to show populism's disintegration dynamics and enrich EI theory by suggesting the introduction of the concept of opposition to gender equality and its analysis of discursive attacks against gender in member states and EU institutions, attention to gender backsliding and gendered de-democratization as indicators of disintegration. Gender approaches also show integrationist dynamics of feminist re-democratization struggles, civil society’s solidarity, and differences within populist discourses with the left developing more progressive equality discourses. Feminist research shows that the gender component is not marginal but rather central in populist discourse and that the EU is associated with the support of gender equality as a value. It is therefore important to adopt gender lenses to make sense of (dis)integration dynamics.

\section{Brexit and postdeconstruction}

Brexit has dominated European politics in 2018 with key dates, negotiations, parliamentary debates and votes in the UK House of Commons. Brexit is the clearest example of disintegration if we consider Webber's (2017: 336) dimension of 'horizontal disintegration' or a simple reduction in the numbers of EU member states (Schimmelfennig, 2017; Rosamond 2016). Since the whole 
phenomenon of Brexit is fraught with strong emotions, we suggest that what we have termed above postdeconstruction is a useful analytical lens.

Postdeconstruction foregrounds the role of emotions and affects in politics, not as an individual but rather as a social phenomenon. Negative emotions about the European integration project are prominent in Brexit. Populist right parties that promoted Brexit mobilised people's emotions of disgust, fear, or anger against migrants and the EU. In doing this, they expressed their own gendered ethos and masculinist attitudes. Arguments for Brexit mobilised nostalgic feelings for an imaginary past as evidence with the slogan "Take Back Control” of the Vote Leave campaign. Whilst positive emotions about the integration project are far harder to articulate in the analysis of Brexit, events such as the London 'Put it to the people' march of 23 March 2019 show integrationist dynamics in the positive feelings and affective attachments to the European project that thousands of people manifested $^{1}$.

Feminist analytical perspectives to Brexit capture the 'highly emotive nature of the debate' and suggest this was ‘deeply gendered’ prior to the 2016 referendum (Guerrina et al., 2018, p. 388). The debate reproduced political binaries of 'high' vs 'low' politics and policy, marginalising social, gender equality, and women concerns (Guerrina et al., 2018). At the same time, media gave minimum visibility to women during the campaign, with $17.5 \%$ of media coverage according to Guerrina et al. (2018, p. 391). The potentially negative effects for gender equality policies in the UK exiting the EU were silenced too (Guerrina and Masselot, 2018). As Guerrina et al. (2018) argue, the symbolic context around the referendum reproduced a gendered public-private dichotomy of political participation in which men represented the 'strong publics', engaged with high political issues of the referendum, and women were represented as the 'weak publics', undecided about their vote, less confident about their knowledge about the EU and showing less political engagement with the referendum's issues (Guerrina et al 2018: 392). The referendum campaign took place in a context of political violence (as exemplified by Jo Cox's murder), aggressiveness, and personal threats in social media against women experts arguing for the remain option.

Brexit negotiations also reflected emotional political contexts full of toxic masculinity (Guerrina, 2019). Political debates have been highly confrontational, focused around winner vs losers, with

\footnotetext{
${ }^{1}$ Adams, Tim (2019) 'Put it to the People march: a formidable sea of humanity and powerful strength of feeling'. The Guardian, 23/3/2019. Available at https://www.theguardian.com/politics/2019/mar/23/put-it-to-the-people-marchagainst-brexit-london-revoke-remain-reform.
} 
politics conceived as a 'winner-takes-it-all' game, in which individual performance and power rather than collective social consequences are considered important. Guerrina (2019) argues that attitudes of 'compromise and cooperation' often associated with 'women's skills' in politics, were presented as 'weakness' to be avoided during negotiations. In her words, 'Acknowledging the interests of underrepresented groups requires empathy, something that has been sadly lacking throughout the Brexit process' (Guerrina, 2019)2 ${ }^{2}$ This attitude disregards the impact of Brexit on underprivileged and under-represented socio-economic groups, and care for their interests, as Fawcett Society and Women's Budget Group have denounced. It also prevents negotiators from exploring all possible options in the search for a way forward in the Brexit challenge.

Overall, when analysed from gender postdeconstructionist approaches, Brexit is not only the clearest example of horizontal disintegration (Webber, 2017), but also a good example of what effects can the marginalization of women's voices and gender perspectives that took place in a context of toxic masculinity have on gender equality and the goals and shaping of European integration. The political consequences of this marginalization of gender issues and positive emotions of empathy towards most unprivileged groups in the Brexit process, as well as the representation of attitudes of compromise during negotiations as weakness include the strengthening of gender and other intersecting inequalities in the political process (Guerrina 2019; Guerrina and Masselot, 2018). For this reason, Guerrina et al (2018, p. 253) urge studies of EI to take gender seriously in the theory, because otherwise this lack 'puts the discipline in danger of reproducing structures of power that keep traditionally marginal groups, including women, ethnic minorities and migrants, on the periphery of the EU project.'. They argue that the construction of knowledge and feelings about the EI political process, and the gender biases in this construction, contributes to shape existing social inequalities in the EU, by promoting or counteracting them.

\section{Conclusion}

In this article, we have explored the impact of the confluence of key events in 2018 on the way we think about European integration and disintegration. Specifically, we argued for a detailed engagement with feminist political analyses in the development of integration and disintegration theories. It has been our contention that feminist political analyses have key contributions to make. And not just any feminist political analyses but three approaches that have had the hardest time in

\footnotetext{
${ }^{2}$ https://inews.co.uk/opinion/comment/brexit-hyper-masculinity-limited-opportunities-alternative-ways-forward/
} 
having an impact on political science and EU studies. These include deconstruction, intersectionality and postdeconstruction. The first focuses on deconstructing dominant discourses and gender norms and showing their impact on political processes; the second foregrounds the ways in which gender is always cut through with other inequalities such as race and ethnicity, class, ability, sexuality, which shape the political realities together with gender; the last perspective illustrates how emotions and affects drive our politics, including European integration and disintegration. In this way, our article has been a plea not just to include a gender perspective in European integration and disintegration debates, but to engage with the insights of these often marginalised perspectives.

Our key contention has been that without an understanding of intersectional gender dynamics and feminist analysis European integration theories will only ever be partial and will continue to struggle to explain disintegration. Gender equality is at the heart of integration and disintegration and subtle and overt attacks against it, scaling down gender equality policies, commitments and priorities, are key signals of the difficulties the European integration project may be facing.

We have illustrated our argument by focusing on three defining cases of 2018: the economic crisis, populism and Brexit. We analysed what an intersectionality approach would reveal of the economic crisis and showed how even more than a mere gender approach it shows the unevenness of integration and disintegration moments. We approached populism through a deconstruction perspective to show the key role that discursive constructions - as prominent and powerful ideas - of the European integration play in populist politics. These constructions are fundamentally underpinned by constructions of gender norms and constructions of the European gender equality project - perhaps as particularly "elite” and to be opposed or as a sign of dangerous "gender ideology" to be opposed. Finally, Brexit illustrates the usefulness of the feminist approach of postdeconstruction which analyses the role that emotions and affects play in politics and in perceptions about European integration and disintegration.

One of our key conclusions is that integration and disintegration are present in all of these cases. For instance, intersectional gender analyses expose the challenge that the economic crisis poses to European integration identifying both disintegration and integration dynamics. While dismantling of EU gender equality policies, marginalization of minoritized women and de-democratization indicate disintegration, intersectional approaches expose integrative dynamics activated by the crisis, such as inclusive processes, re-democratization struggles and some advances in the EU social agenda. 


\section{Bibliography}

Abels, G. and MacRae, H. (2016) 'Why and How to Gender European Integration Theory? Introduction'. In Abels, G and MacRae, H. (eds) Gendering European Integration Theory. Engaging New Dialogues (Berlin: Barbara Budrich Publishers), pp. 9-37.

Ahmed, S. (2004) The Cultural Politics of Emotions (Edinburgh: Edinburgh University Press).

Bieling, H-J. and Diez, T. (2016) 'Linking gender perspectives to integration theory’. In Abels, G. and MacRae, H. (eds) Gendering European Integration Theory. Engaging New Dialogues (Berlin: Barbara Budrich Publishers), pp. 279-292.

Börzel, T.A. and Risse, T. (2018) 'From the euro to the Schengen crises: European integration theories, politicization, and identity politics'. Journal of European Public Policy, Vol. 25, No. 1, pp. 83-108.

Börzel, T. A. (2018) 'Researching the EU (Studies) into demise?' Journal of European Public Policy, Vol. 25, No. 3, pp. 475-485.

Bassel, L. and Emejulu, A. (2017) Minority Women and Austerity: Survival and Resistance in France and Britain (Bristol: Policy Press).

Cavaghan, R. (2017) 'The Gender Politics of EU Economic Policy: Policy Shifts and Contestations before and after the crisis'. In Kantola, J. and Lombardo, E. (eds) Gender and the Economic Crisis in Europe. Politics, Institutions, and Intersectionality (Basingstoke: Palgrave Macmillan), pp. 49-72.

Cavaghan, R. and O'Dwyer, M. (2018) 'European Economic Governance in 2017: A Recovery for Whom?’ Journal of Common Market Studies, Vol 56, No. S1, pp. 96-108.

Coole, D. and Frost, S. (2010) 'Introducing the New Materialisms'. In D. Coole and S. Frost (eds) New Materialisms: Ontology, Agency and Politics (Durham, NC: Duke University Press), pp. 1-46. 
Crenshaw, K. W. (1991) 'Demarginalizing the Intersection of Race and Sex: A Black Feminist Critique of Antidiscrimination Doctrine, Feminist Theory and Antiracist Politics'. In Bartlett, K. and Kennedy, R. (eds) Feminist Legal Theory: Readings in Law and Gender (San Francisco: Westview Press), pp. 57-80.

Elomäki, A. and Kantola, J. (2017) 'Austerity and feminist resistance in Finland: Between established women’s organisations and new movements'. In Kantola, J. and Lombardo, E. (eds) Gender and the Economic Crisis in Europe (Basingstoke: Palgrave Macmillan), pp. 231-255.

Elomäki, A. and Kantola, J. (2018) 'Theorizing feminist struggles in the triangle of neoliberalism, conservatism, and nationalism’. Social Politics, Vol. 25, No. 3, pp 337-360.

Gómez-Reino, M (2018) 'The Populist Nationalist Party Family and the European Cleavage’. In Gómez-Reino, M. Nationalisms in the European Arena: Nationalisms in the European Arena (Basingstoke: Palgrave Macmillan), pp. 63-85.

Guerrina, R. and Masselot, A. (2018) 'Walking into the Footprint of EU Law: Unpacking the Gendered Consequences of Brexit’. Social Policy \& Society. Vol. 17, No. 2, pp. 319-330.

Guerrina, R. (2019) 'Hyper-masculinity in Brexit is stopping us from finding another way forward. i, 28/03/2019. Available at: https://inews.co.uk/opinion/comment/brexit-hyper-masculinity-limitedopportunities-alternative-ways-forward/.

Guerrina, R., Haastrup, T., Wright K.A.M., Masselot, A., MacRae, H. and Cavaghan, R. (2018) 'Does European Union studies have a gender problem? Experiences from researching Brexit'. International Feminist Journal of Politics, Vol. 20, No. 2, pp. 252-257.

Haas, E. B. (1958) The Uniting of Europe: political, social, and economical forces, 1950-1957 (Stanford: Stanford UP).

Haastrup, T. and Kenny, M. (2016) 'Gendering Institutionalism: A Feminist Institutionalist Approach to EU Integration Theory'. In Abels, G. and MacRae, H. (eds) Gendering European Integration Theory (Berlin: Barbara Budrich Publishers), pp. 197-216. 
Hoskyns, C. (2004) 'Gender perspectives'. In Wiener, A. and Diez, T. (eds) European Integration Theory (Oxford: Oxford University Press), pp. 217-236.

International Panel on Social Progress (2016) ‘The challenge of gender inequality'. In Rethinking society for the 21st century (Chapter 14). Available at https://comment.ipsp.org/chapter/chapter-14inequality-challenge-democracy.

Kantola, J. and Lombardo, E. (2017) ‘EU gender equality policies’. In Heinelt, H. and Münch, S. (eds) Handbook of European Policies: Interpretive Approaches to the EU (Cheltenham: Edward Elgar), pp. 331-352.

Kantola, J. and Lombardo, E. (eds) (2017a) Gender and the Economic Crisis in Europe. Politics, Institutions, and Intersectionality (Basingstoke: Palgrave Macmillan).

Kantola, J. \& Lombardo, E. (2017b) Gender and Political Analysis (Basingstoke: Palgrave Macmillan).

Kantola, J. and Lombardo, E. (2019) 'Populism and feminist politics: The cases of Finland and Spain’. European Journal of Political Research. Online first, available at: https://doi.org/10.1111/1475-6765.12333.

Kantola, J. and Rolandsen Agustin, L. (2016) 'Gendering transnational party politics: The case of European Union’. Party Politics, Vol. 22, No. 5, pp. 641-651.

Kantola, J. and Rolandsen Agustin, L. (2019) 'Gendering the representative work of the European Parliament: A political analysis of women MEP's perceptions of gender equality in party groups'. Journal of Common Market Studies. Online first.

Karamessini, M. (2014) ‘Introduction - Women’s vulnerability to recession and austerity. A different context, a different crisis'. In Karamessini, M. and Rubery J. (eds) Women and Austerity: The Economic Crisis and the Future for Gender Equality (London: Routledge), pp. 3-16.

Keskinen, S., Norocel, C. and Jørgensen, M. (2016). The politics and policies of welfare chauvinism under the economic crisis. Critical Social Policy, Vol. 36, No. 3, pp. 321-329. 
Klatzer, E. \& Schlager, C. (2014) 'Feminist perspectives on macroeconomics: reconfiguration of power structures and erosion of gender equality through the new economic governance regime in the European Union'. In Evans, M., Hemmings, C., Henry, M., Madhok, S. and Waring, S. (eds) Feminist Theory Handbook (London: Sage), pp. 483-500.

Kreuder-Sonnen, C. (2018) 'An authoritarian turn in Europe and European Studies?' Journal of European Public Policy, Vol. 25, No. 3, pp. 452-464.

Kronsell, A. (2005) 'Gender, Power and European Integration Theory’. Journal of European Public Policy, Vol. 16, No. 2, pp. 1022-1040.

Kronsell, A. (2012) 'Gendering theories of European integration'. In Abels, G. and Mushaben, J. (eds) Gendering the European Union. New Approaches to Old Democratic Deficits (Basingstoke: Palgrave Macmillan), pp. 23-40.

Kronsell, A. (2016) 'The Power of EU Masculinities: A Feminist Contribution to European Integration Theory’. Journal of Common Market Studies, Vol. 54, No. 1, pp. 104-120.

Kuhar, R. and Paternotte, D. (2017) Anti-gender Campaigns in Europe: Mobilizing against Equality (Lanham, MD: Rowman \& Littlefield).

Köttig, M., Bitzan, R. and Pető, M. (eds) (2017) Gender and Far Right Politics in Europe (Basingstoke: Palgrave Macmillan).

Leruth, B. and Lord, C. (2015) 'Differentiated integration in the European Union: a concept, a process, a system or a theory?' Journal of European Public Policy, Vol. 22, No. 6, pp. 754-763.

Lombardo, E. (2016) 'Social constructivism in European Integration Theories: Gender and Intersectionality Perspectives’. In Abels, G. and MacRae, H. (eds) Gendering European Integration Theory: Engaging New Dialogues (Berlin: Barbara Budrich Publishers), pp. 123-146.

Lombardo, E. (2017) 'The Spanish gender regime in the EU context: changes and struggles in the wake of austerity policies’. Gender, Work \& Organization, Vol. 24, No. 1, pp. 20-33. 
Lombardo, E. and Rolandsen, L. (2016) 'Intersectionality in European Union policymaking: the case of gender-based violence'. Politics, Vol. 36, No. 4, pp. 364-373.

Meret, S. (2015) 'Charismatic female leadership and gender: Pia Kjærsgaard and the Danish People's Party'. Patterns of Prejudice, Vol. 49, No. 1-2, pp. 81-102.

Norocel, C. (2013) 'GGive us back Sweden!' A feminist reading of the (re)interpretations of the folkhem conceptual metaphor in Swedish radical right populist discourse'. Nordic Journal of Feminist and Gender Research, Vol. 21, No. 1, pp. 4-20.

Pedwell, C. (2014) Affective Relations: The Transnational Politics of Empathy (Basingstoke: Palgrave Macmillan).

Pirro, A. L. P. and van Kessel, S. (2017) 'United in opposition? The populist radical right’s EUpessimism in times of crisis'. Journal of European Integration, Vol. 39, No. 4, pp. 405-420.

Rittberger, B. \& Blauberger, M. (2018) 'Introducing the debate section: The EU in crisis: EU studies in crisis?' Journal of European Public Policy, Vol. 25, No. 3, pp. 436-439.

Roggeband, C. \& Krizsán, A. (2018) 'Reversing gender policy progress: patterns of backsliding in Central and Eastern European new democracies'. European Journal of Politics and Gender, Vol. 1, No. 3, pp. 367-385.

Rolandsen Agustín, L. (2013) Gender Equality, Intersectionality and Diversity in Europe (Basingstoke: Palgrave Macmillan).

Rosamond, B. (2016). 'Brexit and the Problem of European Disintegration'. Journal of Contemporary European Research, Vol. 12, no. 4, pp. 864-871.

Schimmelfennig, F. (2017) ‘Theorising Crisis in European Integration’. In Dinan, D., Nugent, N. and Paterson, W.E. (eds) The European Union in Crisis (Basingstoke: Palgrave Macmillan), pp. 316-335. 
Siim, B. Krasteva, A. and Saarinen, A. (eds) (2018) Citizens' Activism and Solidarity Movements: Contending with Populism (Basingstoke: Palgrave Macmillan).

Siim, B., Krizsán, A., Gruziel, D. and Nissen, A. (2016) D9.7 Report of case studies on gender equality as a focus point of national and nativist discourses, 16 June. Available at: http://beucitizen.eu/wp-content/uploads/Report-9-7-Version-16-06-2016.pdf.

Spierings, N. and Zaslove, A. (2015) 'Gendering the vote for populist radical-right parties'. Patterns of Prejudice, Vol. 49, No. 1-2, pp. 135-162.

Verloo, M. (ed) (2007) Multiple Meanings of Gender Equality: A Critical Frame Analysis of Gender Policies in Europe (Budapest: Central European University Press).

Verloo, M. (ed) (2018) Varieties of Opposition to Gender Equality in Europe (London: Routledge).

Verloo, M. \& Patternotte (2018) ‘The Feminist Project under Threat in Europe’. Politics and Governance, Vol. 6, No. 3, pp. 1-5.

Walby, S. (2015) Crisis (Cambridge: Polity press). 